\title{
FAKTOR-FAKTOR YANG BERHUBUNGAN DENGAN PERILAK PEMBERIAN ASI EKSKLUSIF PADA BAYI USIA 6-24 BULAN DI WILAYAH KERJA PUSKESMAS SANGGARAN AGUNG KABUPATEN KERINCI PROVINSI JAMBI
}

\author{
Moza Suzana \\ Akademi Keperawatan Bina Insani Sakti, Provinsi Jambi \\ Email Korespondensi: Mozasuzana45@gmail.com
}

Diterbitkan: 03 Januari 2022

DOI: https://doi.org/10.33024/mnj.v1i1.5752

\section{ABSTRACT: FACTORS RELATED TO EXCLUSIVE BREASTING BEHAVIOR IN INFANTS AGED 6-24 MONTHS IN THE WORK AREA OF SANGGARAN AGUNG PUSKESMAS, KEINCI REGENCY, JAMBI PROVINCE}

Introduction: The problem of exclusive breastfeeding in infants is caused by a lack of mother's knowledge, mother's attitude towards exclusive breastfeeding, busy working mothers, and low maternal education. In Indonesia, the exclusive breastfeeding coverage target is 80\%, according to the 2013 Riskesdas report, the milk adequacy rate of $30.2 \%$ is still below the target.

Objective: To determine the factors associated with exclusive breastfeeding behavior in infants aged 6-24 months in the Sanggaran Agung Community Health Center Work Area in 2020.

Methods: This type of research is quantitative with a cross sectional design. This research was conducted on August 2-10, 2020, with the population being all mothers with children under five in the Sanggaran Agung Health Center Work Area as many as 65 people, and samples were taken using the Total Population technique. Data was collected through a questionnaire sheet. Data were analyzed by univariate and bivariate with Chy Square test.

Results: The results showed the frequency distribution of exclusive breastfeeding behavior (not giving exclusive breastfeeding $46.2 \%$, exclusive breastfeeding 53.8\%), knowledge factor (not good 41.5\%, good 58.5\%), place of delivery (non health facilities) 30.8\%, health facilities 69.2\%), birth attendants (non-health workers $27.7 \%$, health workers $72.3 \%$ ), support from health workers (less supportive $44.6 \%$, supported $55,4 \%$ ) and family support (less supportive $35.4 \%$, supportive $64.6 \%$ ).

Conclusion: Based on the results of the study, it can be concluded that there is a relationship between knowledge of mothers, birthing places, birth attendants, support for health workers and family support with exclusive breastfeeding behavior for infants aged 6-24 months in the Sanggaran Agung Public Health Center, Kerinci Regency, Jambi Province in 2020. Support from health centers and related stakeholders to increase mother's knowledge about exclusive breastfeeding and provide support to mothers to be able to give exclusive breastfeeding to their babies.

Keywords: Knowledge, place of delivery, birth attendant, support for health workers, family support, exclusive breastfeeding behavior 
INTISARI: FAKTOR-FAKTOR YANG BERHUBUNGAN DENGAN PERILAK PEMBERIAN ASI EKSKLUSIF PADA BAYI USIA 6-24 BULAN DI WILAYAH KERJA PUSKESMAS SANGGARAN AGUNG KABUPATEN KERINCI PROVINSI JAMBI

Pendahuluan: Permasalah ASI eklusif pada bayi adalah karena pengetahuan ibu yang kurang, sikap ibu terhadap pemberian ASI eklusif, ibu sibuk kerja, pendidikan ibu yang rendah. Di Indonesia target cakupan ASI ekslusif adalah 80\%, menurut laporan Riskesdas 2013, angka kecukupan ASI sebanyak 30,2\% masih dibawah target.

Tujuan: Tujuan penelitian ini untuk mengetahui faktor-faktor yang berhubungan dengan perilaku pemberian ASI Eksklusif pada bayi Usia 6-24 Bulan Di Wilayah Kerja Puskesmas Sanggaran Agung Tahun 2020.

Metode: Jenis penelitian ini adalah kuantitatif dengan desain Cross Sectional, Penelitian ini telah dilaksanakan pada tanggal 2-10 Agustus 2020, dengan populasi adalah semua ibu yang memiliki baduta di Wilayah Kerja Puskesmas Sanggaran Agung sebanyak 65 orang dan sampel diambil dengan teknik Total Populasi. Pengumpulan data dilakukan melalui lembar kuesioner. Data dianalisa secara univariat dan bivariat dengan Uji Chy Square.

Hasil: Hasil penelitian didapatkan distribusi frekuensi Perilaku pemberian ASI Ekslusif (Tidak ASI Ekslusif 46,2\%, ASI Ekslusif 53,8\%), faktor pengetahuan (kurang baik 41,5\%, Baik 58,5\%), tempat persalinan (Non fasilitas kesehatan 30,8\%, Fasilitas kesehatan 69,2\%), penolong persalinan (non tenaga kesehatan 27,7\%, tenaga kesehatan 72,3\%), dukungan petugas kesehatan (kurang mendukung $44,6 \%$, mendukung $55,4 \%$ ) dan dukungan keluarga (kurang mendukung $35,4 \%$, mendukung $64,6 \%$ ).

Kesimpulan: Berdasarkan hasil penelitian maka dapat disimpulkan bahwa Ada hubungan pengetahuan ibu, tempat persalinan, penolong persalinan, dukungan tenaga kesehatan dan dukungan keluarga dengan perilaku pemberian ASI eksklusif pada bayi usia 6-24 bulan di Wilayah Kerja Puskesmas Sanggaran Agung Tahun Kabupaten Kerinci Provinsi Jambi 2020. Dukungan dari pihak puskesmas dan stakeholder terkait untuk dapat meningkatkan pengetahuan ibu tentang ASI Ekslusif serta memberikan dukungan bagi ibu untuk dapat memberikan ASI Ekslusif untuk bayinya.

Kata Kunci : Pengetahuan, tempat persalinan, penolong persalinan, dukungan tenaga kesehatan, dukungan keluarga, Perilaku Pemberian ASI Ekslusif

\section{PENDAHULUAN}

Pembangunan kesehatan pada periode 2015-2019 adalah Program Indonesia Sehat dengan sasaran meningkatkan derajat kesehatan dan status gizi masyarakat yang didukung dengan perlindungan finansial dan pemerintah pelayanan kesehatan. Salah satu sasaran pokok Rencana Pembangunan Jangka Menengah Nasional (RPJMN) 20152019 adalah meningkatnya status kesehatan gizi ibu dan anak
(Kemenkes, 2015).

Peningkatan kualitas sumber daya manusia dimulai sejak masa hamil, bayi, anak sekolah, dewasa, sampai usia lanjut atau yang dikenal dengan perjalanan siklus kehidupan. Setiap saat dari siklus tersebut manusia memerlukan makanan yang berbeda-beda dan harus dipenuhi secara tepat. Pola pemberian makanan terbaik bagi bayi dan anak menurut (WHO) adalah memberikan hanya ASI saja kepada bayi sejak 
lahir sampai dengan umur 6 bulan (ASI eklusif), Meneruskan pemberian ASI sampai umur 24 bulan dan memberikan makanan pendamping AS I (MP-ASI) kepada bayi mulai usia 6 bulan (Kemenkes RI, 2011). Wijayanti

(2010) menyimpulkan bahwa angka kejadian diare pada bayi umur 0-6 bulan yang mendapatkan ASI ekslusif lebih sedikit bila dibandingkan dengan bayi yang tidak mendapatkan Asi eklusif. Hal itu dikarenakan ASI merupakan asupan yang aman dan bersih bagi bayi dan mengandung antibody penting yang ada dalam kolostrum. Menurut Utari (2013), pola pemberian ASI yang baik akan mengurangi keluhan kesehatan pada ibu postpartum.

\begin{tabular}{lrr}
\multicolumn{3}{c}{ Dalam Penelitian Nur Rahman } \\
(2017) beberapa faktor & diduga \\
menyebabkan & bayi & tidak \\
mendapatkan ASI dengan baik.
\end{tabular} Faktor tersebut adalah factor karakteristik Ibu, dukungan keluarga, pendidikan, dll. Selain itu, berdasarkan beberapa laporan studi tentang permasalah ASI eklusif pada bayi adalah karena pengetahuan ibu yang kurang, sikap ibu terhadap pemberian ASI eklusif, ibu sibuk kerja, pendidikan ibu yang rendah, gencarnya periklanan tentang penggunaan susu formula, kurangnya sekresi ASI, presepsi tentang bayi tanpa diberi makanan tambahan akan menjadi lapar dan pengetahuan ibu tentang ASI kurang.

Di Indonesia target cakupan ASI ekslusif adalah $80 \%$, menurut laporan Riskesdas 2013 bahwa angka kecukupan ASI 24 jam untuk kelompok umur 6 bulan merupakan data bayi yang mendapatkan ASI saja dalam 24 jam terakhir dan tidak diberikan makanan prelakteal sebanyak 30,2\%. Data profil kesehatan Jambi, tahun 2015 cangkupan pemberian ASI eklusif di Provinsi Jambi adalah 55,69\%. Dan di Kerinci pemberian ASI eklusif sebanyak $69.68 \%$.

Berdasarkan data DINKES

Kabupaten Kerinci tahun 2019, terjadi penurunan dari tahun 2017 hingga 2019 didapatkan cangkupan ASI eklusif sebanyak 46,5\% dari 6 kecamatan. Dan salah satunya Kecamatan Danau kerinci, berdasarkan data yang diperoleh di Puskesmas Sanggaran agung bayi yang mendapatkan ASI eklusif selama 6 bulan hanya $48,2 \%$. Cangkupan ini masih jauh dibawah target pencapaian pemberian ASI Eklusif Nasional yaitu $80 \%$.

Di Puskesmas Sanggaran agung pada tahun 2020 terdapat 336 bayi, menurut wawancara dengan bidan desa di Wilayah Kerja Puskesmas vdidapat dari data kelahiran tersebut, bayi yang tidak menyusui secara ekslusif sebanyak 45 orang bayi, kejadian tersebut mencapai 13,35\% dari angka kelahiran. Adapun bayi yang tidak menyusui secara ekslusif dikarenakan faktor ASI yang tidak lancar dan kurangnya pengetahuan ibu tentang manfaat ASI ekslusif untuk bayi.

Data jumlah baduta di Wilayah Kerja Puskesmas Sanggaran agung dari Januari sampai Mei Tahun 2021 adalah sebanyak 65 orang (Puskesmas Sanggaran agung, 2020). Sampai saat ini, banyak informasi dan berita mengenai rendahnya persentase pemberian ASI eksklusif pada bayi usia sampai 6 bulan dan pengaruhnya terhadap status gizi dan kesehatan bayi. Sehingga, rendahnya pemberian ASI eksklusif masih perlu pengkajian dan pembelajaran, terutama darifaktor penyebab seperti umur, karena usia ibu mempengaruhi kesiapan emosi ibu. Usia ibu terlalu muda menyebabkan kondisi fisiologis dan psikologisnya belum siap menjadi ibu, hal ini dapat mempengaruhi kehamilan dan pengasuhan anak.

Pengetahuan ibu tentang ASI 
merupakan salah satu factor yang penting dalam kesuksesan proses menyusui. Abdullah et al (2004) menyatakan bahwa tingkat pengetahuan, pendidikan, status kerja ibu dan jumlah anak dalam keluarga berpengaruh positif dan pola peberian ASI. Tempat bersalin dan penolong bersalin akan memungkinkan ibu mendapat info lebih baik tentang ASI, dan dukungan petugas kesehatan serta dukungan keluarga akan memotivasi ibu memberikan ASI eklusif.

\section{METODE}

Jenis penelitian yang digunakan dalam penelitian ini adalah penelitian kuantitatif dengan desain penelitian Cross Sectional. Dimana variabel independen dan variabel dependen dikumpulkan dan diteliti dalam waktu yang bersamaan. Penelitian ini menganalisis faktor-faktor yang berhubungan dengan perilaku pemberian ASI eklusif pada bayi Usia 6-24 Bulan di Wilayah Kerja Puskesmas Sanggaran agung Kabupaten kerinci Provinsi Jambi 2020. Variabel dependent dalam penelitian ini adalah perilaku pemberian ASI Eksklusif dan variabel independentnya adalah pengetahuan ibu, tempat persalinan, penolong persalinan, dukungan petugas kesehatan dan dukungan keluarga.

\section{HASIL DAN PEMBAHASAN}

1. Karakteristik Responden

\section{Tabel 1}

a. Distribusifrekuensi karakteristik Puskesmas Sanggarang agung Tahun 2020

\begin{tabular}{|c|c|c|c|}
\hline NO & $\begin{array}{c}\text { Karakteristik } \\
\text { Responden }\end{array}$ & $F$ & $\%$ \\
\hline 1 & $\begin{array}{l}\text { Umur } \\
\text { a. }<20 \text { tahun } \\
\qquad \geq 20 \text { tahun }\end{array}$ & $\begin{array}{l}7 \\
58\end{array}$ & $\begin{array}{r}10,8 \\
89,2\end{array}$ \\
\hline 2 & $\begin{array}{l}\text { Umur Anak } \\
\text { a. } 6-12 \text { bulan } \\
13-24 \text { bulan }\end{array}$ & $\begin{array}{c}34 \\
31\end{array}$ & ${ }_{47,7}^{52,3}$ \\
\hline 3 & $\begin{array}{l}\text { Tingkat Pendidikan Ibu } \\
\text { a. SD } \\
\text { b. SMP } \\
\text { c. SMA } \\
\text { d. PT }\end{array}$ & $\begin{array}{l}10 \\
14 \\
31 \\
10\end{array}$ & $\begin{array}{l}15,4 \\
21,5 \\
47,7 \\
15,4\end{array}$ \\
\hline 4 & $\begin{array}{l}\text { Status Pekerjaan Ibu } \\
\text { a. Pegawai Negeri } \\
\text { b. Karyawan Swasta } \\
\text { c. Wiraswasta } \\
\text { d. IRT } \\
\text { e. Petani }\end{array}$ & $\begin{array}{c}8 \\
1 \\
24 \\
32 \\
0\end{array}$ & $\begin{array}{l}12,3 \\
1,5 \\
36,9 \\
49,2 \\
0\end{array}$ \\
\hline
\end{tabular}

Dari hasil analisis distribusi frekuensi responden berdasarkan tabel 1 menunjukkan bahwa dari 65 responden, berdasarkan umur ibu 
mayoritas terdapat pada usia $\geq 20$ tahun sebanyak 58 responden $(89,2 \%)$, dan minoritas terdapat

Berdasarkan umur anak, mayoritas responden memiliki anak dengan usia 6 - 12 bulan sebanyak 34 responden $(52,3 \%)$, dan minoritas responden memiliki anak dengan usia 13 - 24 bulan sebanyak 31 responden $(47,7 \%)$.

Berdasarkan tingkat pendidikan, mayoritas responden dengan tingkat pendidikan SMA sebanyak 31 ressponden $(47,7 \%)$, dan minoritas pada usia $<20$ tahun sebanyak 7 responden $(10,8 \%)$.

responden dengan tingkat
pendidikan SD dan Perguruan Tinggi
masing-masing sebanyak 10
responden (15,4\%)
Berdasarkan status pekerjaan,
mayoritas responden dengan status
pekerjaan sebagai IRT sebanyak 32
responden (49,2\%) dan minoritas
responden dengan status pekerjaan
petani $0 \%$.

responden dengan tingkat pendidikan SD dan Perguruan Tinggi masing-masing responden $(15,4 \%)$

Berdasarkan status pekerjaan, mayoritas responden dengan status responden $(49,2 \%)$ dan minoritas petani $0 \%$.

\section{Analisis Univariat}

\section{Tabel 2}

b. Distribusi Frekuensi Perilaku Pemberian ASI Ekslusif di Wilayah Kerja Puskesmas Sanggarang agung Tahun 2020

\section{Tabel 4.2}

\begin{tabular}{ccc}
\hline Perilaku ASI Ekslusif & f & $\%$ \\
\hline Tidak ASI Ekslusif & 30 & 46,2 \\
ASI Ekslusif & 35 & 53,8 \\
\hline Jumlah & $\mathbf{6 5}$ & $\mathbf{1 0 0}$
\end{tabular}

Dari hasil analisis distribusi frekuensi berdasarkan tabel 2 menunjukkan bahwa lebih separuh $(53,8 \%)$ responden yang ASI Ekslusif. Mayoritas responden sudah ASI
Ekslusif sebanyak 35 responden $(53,8 \%)$, dan minoritas responden yang tidak ASI Ekslusif sebanyak 30 responden $(46,2 \%)$.

\section{b. Distribusi Frekuensi Pengetahuan Ibu di Wilayah Kerja Puskesmas Sanggarang agung Tahun 2020}

Tabel 3

\begin{tabular}{lcc}
\hline \multicolumn{1}{c}{ Pengetahuan Ibu } & f & $\%$ \\
\hline Kurang Baik & 27 & 41,5 \\
Baik & 38 & 58,5 \\
\hline Jumlah & 65 & 100 \\
\hline
\end{tabular}

Dari hasil analisis distribusi frekuensi berdasarkan tabel 3 menunjukkan bahwa lebih separuh $(58,5 \%)$ responden memiliki pengetahuan yang baik. Mayoritas responden memiliki pengetahuan baik sebanyak 38 responden $(58,5 \%)$ dan minoritas responden memiliki pengetahuan kurang baik sebanyak 27 responden $(41,5 \%)$. 


\section{c. Distribusi Frekuensi Tempat Persalinan di Wilayah Kerja Puskesmas Sanggarang agung Tahun 2020}

\section{Tabel 4}

\begin{tabular}{ccc}
\hline Tempat Persalinan & f & $\%$ \\
\hline Non Fasilitas Kesehatan & 20 & 30,8 \\
Fasilitas Kesehatan & 45 & 69,2 \\
\hline jumlah & $\mathbf{6 5}$ & $\mathbf{1 0 0}$ \\
\hline
\end{tabular}

Dari hasil analisis distribusi frekuensi berdasarkan tabel 4 menunjukkan bahwa lebih separuh $(69,2 \%)$ responden melakukan persaalinan di fasilitas kesehatan. Mayoritas responden melahirkan di fasilitas kesehatan sebanyak 45 responden $(69,2 \%)$ dan minoritas responden yang melahirkan di Non fasilitas Kesehatan sebanyak 20 responden $(30,8 \%)$.

\section{d. Distribusi Frekuensi Penolong Persalinan di Wilayah Kerja Puskesmas} Sanggarang agung Tahun 2020

Tabel 5

\begin{tabular}{ccc}
\hline Penolong Persalinan & $\mathbf{f}$ & $\%$ \\
\hline Non Tenaga Kesehatan & 18 & 27,7 \\
Tenaga Kesehatan & 47 & 72,3 \\
\hline jumlah & 65 & 100 \\
\hline
\end{tabular}

Dari hasil analisis distribusi frekuensi berdasarkan tabel 5 menunjukkan bahwa lebih separuh $(72,3 \%)$ responden melakukan persalinan di tenaga kesehatan. Mayoritas responden yang menolong persalinannya adalah tenaga kesehatan sebanyak 47 responden $(72,3 \%)$ dan minoritas responden yang melahirkan di Non tenaga Kesehatan sebanyak 18 responden $(27,7 \%)$.

\section{e. Distribusi Frekuensi Dukungan Tenaga Kesehatan di Wilayah Kerja Puskesmas Sanggarang agung Tahun 2020}

Tabel 4.6

\begin{tabular}{ccc}
\hline $\begin{array}{c}\text { Dukungan Tenaga } \\
\text { Kesehatan }\end{array}$ & $\mathbf{f}$ & $\%$ \\
\hline $\begin{array}{c}\text { Kurang Mendukung } \\
\text { Mendukung }\end{array}$ & 29 & 44,6 \\
\hline Jumlah & $\mathbf{6 5}$ & $\mathbf{1 0 0}$ \\
\hline
\end{tabular}

Dari hasil analisis distribusi frekuensi berdasarkan tabel 6 menunjukkan bahwa lebih separuh $(55,4 \%)$ responden mendapat dukungan dari tenaga kesehatan. Mayoritas responden mendapat dukungan dari tenaga kesehatan sebanyak 36 responden $(55,4 \%)$ dan minoritas responden kurang dalam mendapat dukungan sebanyak 29 responden $(44,6 \%)$. 
a. Distribusi Frekuensi Dukungan Keluarga di Wilayah Kerja Puskesmas Sanggarang agung Tahun 2020

Tabel 7

\begin{tabular}{ccc}
\hline Dukungan Keluarga & $\mathbf{f}$ & $\%$ \\
\hline Kurang Mendukung & 23 & 35,4 \\
Mendukung & 42 & 64,6 \\
\hline jumlah & 65 & 100 \\
\hline
\end{tabular}

Dari hasil analisis distribusi frekuensi berdasarkan tabel 7 menunjukkan bahwa lebih separuh $(64,6 \%)$ responden mendapat dukungan dari anggota keluarga. Mayoritas responden mendapat dukungan dari anggota keluarga yang lain sebanyak 42 responden $(64,6 \%)$ dan minoritas responden kurang mendapat dukungan dari anggota keluarga yang lain sebanyak 23 responden $(35,4 \%)$.

\section{Analisis Bivariat}

a. Hubungan pengetahuan ibu dengan perilaku pemberian ASI eksklusif

Tabel .8

\begin{tabular}{|c|c|c|c|c|c|c|c|}
\hline \multirow{3}{*}{$\begin{array}{l}\text { Pengetahuan } \\
\text { Ibu }\end{array}$} & \multicolumn{4}{|c|}{ Perilaku Pemberian ASI } & \multirow[t]{2}{*}{ Jumlah } & \multirow[t]{3}{*}{ p-value } & \multirow{2}{*}{$\begin{array}{l}\text { OR } \\
(95 \% \mathrm{Cl}\end{array}$} \\
\hline & \multicolumn{2}{|c|}{$\begin{array}{c}\text { Tidak ASI } \\
\text { Ekslusif }\end{array}$} & \multicolumn{2}{|c|}{ ASI Ekslusif } & & & \\
\hline & $f$ & $\%$ & $\mathrm{f}$ & $\%$ & $f$ & & \\
\hline Kurang Baik & 7 & 25,9 & $\begin{array}{l}2 \\
0\end{array}$ & 74,1 & 27 & 0,012 & $\begin{array}{c}0.228 \\
(0.078\end{array}$ \\
\hline Baik & $\begin{array}{l}2 \\
3\end{array}$ & 60,5 & $\begin{array}{l}1 \\
5\end{array}$ & 39,5 & 38 & & $0.671)$ \\
\hline jumlah & $\begin{array}{l}3 \\
0\end{array}$ & 46.2 & $\begin{array}{l}3 \\
5\end{array}$ & 53,8 & 65 & & \\
\hline
\end{tabular}

Berdasarkan tabel 8 terlihat bahwa dari 65 responden, mayoritas memiliki pengetahuan baik namun perilaku pemberian ASI Ekslusifnya Tidak ASI Ekslusif sebanyak 23 responden $(60,5 \%)$ dan minoritas responden memiliki pengetahuan kurang baik yang perilaku pemberian ASInya Tidak ASI Eksusif sebanyak 7 responden (25,9\%). Hasil uji statistik diperoleh nilai $p=0,012(<p$ 0,05) berarti $\mathrm{H}_{0}$ ditolak Ha diterima, maka dapat disimpulkan bahwa ada hubungan yang signifikan antara pengetahuan ibu dengan perilaku pemberian ASI Ekslusif pada bayi usia 6-24 bulan di Wilayah Kerja Puskasmas sanggaran agung Kabupaten Kerinci Provinsi Jambi tahun 2020. 
b. Hubungan tempat persalinan dengan perilaku pemberian ASI eksklusif

Tabel 9

Hubungan Tempat Persalinan dengan perilaku pemberian ASI eksklusif pada bayi usia 6-24 bulan di Wilayah Kerja Puskesmas Snggaran agung Kabupaten Kerinci Provinsi Jambi 2020

\begin{tabular}{|c|c|c|c|c|c|c|c|c|}
\hline \multirow{3}{*}{$\begin{array}{c}\text { Tempat } \\
\text { persalinan }\end{array}$} & \multicolumn{4}{|c|}{ Perilaku Pemberian ASI } & \multicolumn{2}{|c|}{ jumlah } & \multirow{2}{*}{$\begin{array}{l}\mathrm{p} \text { - } \\
\text { value }\end{array}$} & \multirow{2}{*}{$\begin{array}{l}\text { OR } \\
\mathbf{( 9 5 \%} \\
\text { C }\end{array}$} \\
\hline & \multicolumn{2}{|c|}{$\begin{array}{l}\text { Tidak ASI } \\
\text { Ekslusif }\end{array}$} & \multicolumn{2}{|c|}{$\begin{array}{l}\text { ASI } \\
\text { Ekslusif }\end{array}$} & & & & \\
\hline & f & $\%$ & f & $\%$ & $f$ & $\%$ & & \\
\hline Non faskes & 5 & $\begin{array}{c}25, \\
0\end{array}$ & $\begin{array}{l}1 \\
5\end{array}$ & $\begin{array}{c}75 \\
0\end{array}$ & 20 & 100 & 0,044 & $\begin{array}{l}0.26 \\
7\end{array}$ \\
\hline Faskes & 25 & $\begin{array}{c}55, \\
6\end{array}$ & $\begin{array}{l}2 \\
0\end{array}$ & $\begin{array}{c}44 \\
4\end{array}$ & 45 & 100 & & $\begin{array}{l}(0.0 \\
83-\end{array}$ \\
\hline jumlah & 30 & $\begin{array}{c}46, \\
2\end{array}$ & $\begin{array}{l}3 \\
5\end{array}$ & $\begin{array}{c}53 \\
8\end{array}$ & 65 & 100 & & $\begin{array}{l}0.86 \\
0)\end{array}$ \\
\hline
\end{tabular}

Berdasarkan tabel 9 terlihat bahwa dari 65 responden, mayoritas tempat persalinan responden di fasilitas pelayanan kesehatan dengan perilaku pemberian ASI Ekslusif sebanyak 25 responden $(55,6 \%)$ dan minoritas tempat persalinan responden di non fasilitas kesehatan sebanyak 5 responden $(25,0 \%)$. Hasil uji statistik diperoleh nilai $p=0,044$
(< $\mathrm{p} 0,05)$ berarti $\mathrm{H}_{0}$ ditolak $\mathrm{Ha}$ diterima, maka dapat disimpulkan bahwa ada hubungan yang signifikan antara ttempat perslainan ibu dengan perilaku pemberian ASI Ekslusif pada bayi usia 6-24 bulan di Wilayah Kerja Puskasmas sanggaran agung Kabupaten Kerinci Provinsi Jambi tahun 2020.

c. Hubungan penolong persalinan dengan perilaku pemberian ASI eksklusif Tabel 4.10Hubungan penolong persalinan dengan perilaku pemberian ASI eksklusif pada bayi usia 6-24 bulan di Wilayah Kerja Puskesmas Sanggaran agung Kabupaten Kerinci Provinsi Jambi 2020

\begin{tabular}{|c|c|c|c|c|c|c|c|c|}
\hline \multirow{3}{*}{$\begin{array}{l}\text { penolong } \\
\text { persalinan }\end{array}$} & \multicolumn{4}{|c|}{ Perilaku Pemberian ASI } & \multicolumn{2}{|c|}{ jumlah } & \multirow{2}{*}{$\begin{array}{c}\mathrm{p}- \\
\text { value }\end{array}$} & \multirow{2}{*}{$\begin{array}{c}\text { OR } \\
(95 \%)\end{array}$} \\
\hline & \multicolumn{2}{|c|}{$\begin{array}{c}\text { Tidak ASI } \\
\text { Ekslusif }\end{array}$} & \multicolumn{2}{|c|}{ ASI Ekslusif } & & & & \\
\hline & $f$ & $\%$ & $f$ & $\%$ & $f$ & $\%$ & & \\
\hline Non Nakes & 4 & 22.2 & 14 & 77,8 & 18 & 100 & 0,034 & 0.231 \\
\hline Nakes & $\begin{array}{l}2 \\
6\end{array}$ & 55,3 & 21 & 44,6 & 47 & 100 & & $\begin{array}{l}(0.066- \\
0.806)\end{array}$ \\
\hline jumlah & $\begin{array}{l}3 \\
0\end{array}$ & 46,2 & 35 & 53,8 & 65 & $\begin{array}{c}10 \\
0\end{array}$ & & \\
\hline
\end{tabular}


Berdasarkan tabel 10 terlihat bahwa dari 65 responden, mayoritas responden yang penolong persalinannya tenaga kesehatan memiliki perilaku pemberian ASI tidak ASI Ekslusif sebanyak 26 responden $(55,3 \%)$ dan minoritas responden yang penolong persalinannya non kesehatann memiliki perilaku pemberian ASI Ekslusif sebanyak 4 responden
$(22,2 \%)$. Hasil uji statistik diperoleh nilai $\mathrm{p}=0,034(<\mathrm{p} 0,05)$ berarti $\mathrm{H}_{0}$ ditolak Ha diterima, maka dapat disimpulkan bahwa ada hubungan yang signifikan antara penolong persalinan ibu dengan perilaku pemberian ASI Ekslusif pada bayi usia 6-24 bulan di Wilayah Kerja Puskasmas sanggaran agung Kabupaten Kerinci Provinsi Jambi tahun 2020.

d.Hubungan Dukungan Tenaga Kesehatan dengan perilaku pemberian ASI eksklusif

Tabel 11

Hubungan Dukungan Tenaga Kesehatan dengan perilaku pemberian ASI eksklusif pada bayi usia 6-24 bulan di Wilayah Kerja Puskesmas Sanggaran agung Kabupaten Kerinci Provinsi Jambi 2020

\begin{tabular}{|c|c|c|c|c|c|c|c|c|}
\hline \multirow{3}{*}{$\begin{array}{l}\text { Dukungan } \\
\text { Tenaga } \\
\text { Kesehatan }\end{array}$} & \multicolumn{4}{|c|}{ Perilaku Pemberian ASI } & \multicolumn{2}{|c|}{ jumlah } & \multirow{3}{*}{$\begin{array}{l}\text { p-value } \\
0,039\end{array}$} & \multirow{3}{*}{$\begin{array}{c}\begin{array}{c}\text { OR } \\
(95 \% \mathrm{C}\end{array} \\
3.273 \\
(1.179- \\
9.087)\end{array}$} \\
\hline & \multicolumn{2}{|c|}{$\begin{array}{l}\text { Tidak ASI } \\
\text { Ekslusif }\end{array}$} & \multicolumn{2}{|c|}{$\begin{array}{l}\text { ASI } \\
\text { Ekslusif }\end{array}$} & & & & \\
\hline & $f$ & $\%$ & $f$ & $\%$ & $f$ & $\%$ & & \\
\hline $\begin{array}{l}\text { Kurang } \\
\text { mendukung }\end{array}$ & 18 & 62,1 & 11 & 37,9 & 29 & 100 & & \\
\hline mendukung & 12 & 33,3 & 24 & 66,7 & 36 & 100 & & \\
\hline jumlah & 30 & 46,2 & 35 & 53,8 & 65 & 100 & & \\
\hline
\end{tabular}

Berdasarkan tabel 11 terlihat bahwa dari 65 responden, mayoritas responden yang mendapat dukungan dari tenaga kesehatan memiliki perilaku pemberian ASI Ekslusif sebanyak 24 responden $(66,7 \%)$, dan minoritas responden kurang mendapat dukungan tenaga kesehatan memiliki perilaku pemberian ASI Ekslusif sebanyak 11 responden (37,9\%). Hasil uji statistik diperoleh nilai $p=0,039(<p$ 0,05) berarti $\mathrm{H}_{0}$ ditolak Ha diterima, maka dapat disimpulkan bahwa ada hubungan yang signifikan antara dukunga tenaga kesehatan dengan perilaku pemberian ASI Ekslusif pada bayi usia 6-24 bulan di Wilayah Kerja Puskasmas sanggaran agung Kabupaten Kerinci Provinsi Jambi tahun 2020. 


\section{e. Hubungan Dukungan Keluarga dengan perilaku pemberian ASI eksklusif}

Tabel 12

Hubungan Dukungan Keluarga dengan perilaku pemberian ASI eksklusif pada bayi usia 6-24 bulan di Wilayah Kerja Puskesmas Sanggaran agung Kabupaten Kerinci Provinsi Jambi 202

\begin{tabular}{|c|c|c|c|c|c|c|c|c|}
\hline \multirow{3}{*}{$\begin{array}{l}\text { Dukungan } \\
\text { Keluarga }\end{array}$} & \multicolumn{4}{|c|}{ Perilaku Pemberian ASI } & \multicolumn{2}{|c|}{ jumlah } & \multirow{2}{*}{$\begin{array}{c}\mathrm{p}- \\
\text { value }\end{array}$} & \multirow{2}{*}{$\begin{array}{c}\text { OR } \\
(95 \% \mathrm{C}\end{array}$} \\
\hline & \multicolumn{2}{|c|}{$\begin{array}{l}\text { Tidak ASI } \\
\text { Ekslusif }\end{array}$} & \multicolumn{2}{|c|}{$\begin{array}{c}\text { ASI } \\
\text { Ekslusif }\end{array}$} & & & & \\
\hline & $f$ & $\%$ & $f$ & $\%$ & $f$ & $\%$ & & \\
\hline $\begin{array}{c}\text { Kurang } \\
\text { mendukung }\end{array}$ & 15 & 65,2 & 8 & 34,8 & 23 & 100 & 0,043 & $\begin{array}{r}3.375 \\
(1.163-\end{array}$ \\
\hline mendukung & 15 & 35,7 & 27 & 64,3 & 42 & 100 & & $9.792)$ \\
\hline jumlah & 30 & 46,2 & 35 & 53,8 & 65 & 100 & & \\
\hline
\end{tabular}

Berdasarkan tabel 12 terlihat bahwa dari 65 responden, mayoritas responden mendapat dukungan keluarga dan perilaku pemberian ASI Ekslusif sebanyak 27 responden (64,3\%), dan minoritas responden tidak mendapat dukungan keluarga namun perilaku pemberian ASI Ekslusif sebanyak 8 responden $(34,8 \%)$. Hasil uji statistik diperoleh

\section{KESIMPULAN}

Berdasarkan hasil dan pembahasan maka dapat simpulkan bahwa Dari hasil yang dilakukan pada 65 orang ibu yang memiliki baduta di Wilayah Kerja Puskesmas sangganran agung tahun 2020 dan dari pembahasan yang telah diuraikan sebelumnya, maka dapat ditarik beberapa kesimpulan yaitu:

Distribusi frekuensi Perilaku ASI Ekslusif (Tidak ASI Ekslusif 46,2\%, ASI Ekslusif 53,8\%), faktor pengetahuan (kurang baik 41,5\%, Baik 58,5\%), tempat persalinan (Non fasilitas kesehatan $30,8 \%$, Fasilitas kesehatan 69,2\%), penolong

\section{DAFTAR PUSTAKA}

Afifah. (2009). Buku Pintar Merawat Bayi. Yogyakarta : Nuha Medika Amalia. Yosvsyah. (2009). Perilaku Yang Menghambat Pemberian nilai $\mathrm{p}=0,043(<\mathrm{p} 0,05)$ berarti $\mathrm{H}_{0}$ ditolak Ha diterima, maka dapat disimpulkan bahwa ada hubungan yang signifikan antara dukunga keluarga dengan perilaku pemberian ASI Ekslusif pada bayi usia 6-24 bulan di Wilayah Kerja Puskasmas Sanggaran agung Kabupaten Kerinci Provinsi Jambi 2020

persalinan (non tenaga kesehatan $27,7 \%$, tenaga kesehatan $72,3 \%$ ), dukungan petugas kesehatan (kurang mendukung 44,6\%, mendukung $55,4 \%$ dan dukungan keluarga (kurang mendukung $35,4 \%$, mendukung 64,6\%) di Wilayah Kerja Puskesmas Sanggaran agung Kabupaten Kerinci Provinsi Jambi 2020

Ada hubungan pengetahuan ibu dengan perilaku pemberian ASI eksklusif pada bayi usia 6-24 bulan di Wilayah Kerja Puskesmas S Sanggaran agung Kabupaten Kerinci Provinsi Jambi 2020 dengan $\mathrm{p}$ value $=0,012$.

ASI Eklusif Pada Ibu Di Wilayah Kerja Puskesmas Cibeber Tahun 2009.

Depkes RI. (2009). Pedoman Pemantauan Wilayah Setempat 
Kesehatan Ibu Dan Anak (PWSKIA). Jakarta

Dinas Kesehatan Kabupaten Kerinci. (2019). Cakupan pemberian ASI Ekslusif di Kabupaten Kerinci 2019

Fikawati, Sandra Dan Syafiq, Ahmad. (2009). Penyebab Keberhasilan Dan Kegagalancpraktik Pemberian ASI Eksklusif. Jurnal Kesehatan Masyarakat Nasional. 3 Desember 2009. Penerbit FKM UI.

Green, Lawrence, Et Al. (1980). Health Education Planning : A Diagnostic Approach. The John Hopkins University. Mayfield Publishing Company.

Kemeterian Kesehatan RI. (2015). Program Indonesia sehat 20152019.

Kementerian Kesehatan, RI. (2011). Peningkatan Kualitas Sumber Daya Manusia.

Kristiyansari. (2009). ASI, Menyusui Dan Sadari. Yogyakarta : Nuha Medika

Lestari, Dian. (2013). Hubungan Tingkat Pengetahuan Ibu Dan Pekerjaan Ibu Dengan Pemberian ASI Eksklusif Dikelurahan Fajar Bulan. Skripsi.

Notoatmodjo, S. (2010). Ilmu Perilaku Kesehatan. Jakarta : Rineka Cipta.

Notoatmodjo, S. (2012). Ilmu
Pendidikan Kesehatan Dan Perilaku Kesehatan. Jakarta : Rineka Cipta.

Nurpelita. (2007). Faktor-Faktor Yang Berhubungan Dengan Pemberian ASI Eklusif Diwilayah Kerja Puskesmas Buatan II Siak Tahun 2007. Tesis. Depok : FKM UI

Nur Rahman. (2017). Pengetahuan Sikap Pemberian Asi Eklusif Diwilayah Kerja Puskesmas Jumpadang Baru Kecamatan Tallo Kota Makassar. Skripsi.

Nursalam, (2018). Pendekatan Praktis Metodologi Riset Keperawatan. Jakarta ; Salemba Medika.

Profil Kesehatan Jambi. (2015). Presentase Bayi yang Diberikan ASI Eklusif. Hal : 116

Puskesmas Sanggaran agung . (2020). Cakupan Pemberian ASI Ekslusif di Wilayah Kerja Puskesmas Siulak Mukai.

Riordan J. (2004). The Biological Specificity Of Breast Milk. In: Breastfeeding And Human Lactation. Boston, USA : Jones And Bartlett.

Roesli, Utami. (2009). Mengenal ASI Eksklusif. Jakarta : Trubus Agriwidya

Riset Kesehatan Dasar. (2013). Pola Pemberian ASI. Hal : 202

World Health Organization. (2016). Manfaat ASI Bagi Bayi. Geneva WHO 